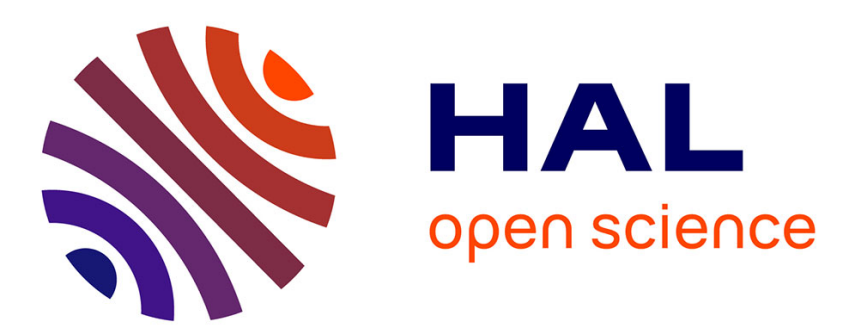

\title{
A new combined green method for 2-Chlorophenol removal using cross-linked Brassica rapa peroxidase in silicone oil.
}

Nassima Tandjaoui, Mahmoud Abouseoud, Annabelle Couvert, Abdeltif Amrane, Amina Tassist

\section{To cite this version:}

Nassima Tandjaoui, Mahmoud Abouseoud, Annabelle Couvert, Abdeltif Amrane, Amina Tassist. A new combined green method for 2-Chlorophenol removal using cross-linked Brassica rapa peroxidase in silicone oil.. Chemosphere, 2016, 148, pp.55-60. 10.1016/j.chemosphere.2016.01.021 . hal-01263046

HAL Id: hal-01263046

https://hal-univ-rennes1.archives-ouvertes.fr/hal-01263046

Submitted on 31 May 2016

HAL is a multi-disciplinary open access archive for the deposit and dissemination of scientific research documents, whether they are published or not. The documents may come from teaching and research institutions in France or abroad, or from public or private research centers.
L'archive ouverte pluridisciplinaire HAL, est destinée au dépôt et à la diffusion de documents scientifiques de niveau recherche, publiés ou non, émanant des établissements d'enseignement et de recherche français ou étrangers, des laboratoires publics ou privés. 


\section{A new combined green method for 2-Chlorophenol removal using cross-linked Brassica rapa peroxidase in silicone oil.}

TANDJAOUI Nassima ${ }^{\mathrm{a}, \mathrm{c}}$, ABOUSEOUD Mahmoud ${ }^{\mathrm{a}, \mathrm{b}}$, COUVERT Annabelle $^{\mathrm{c}, \mathrm{d}}$, AMRANE Abdeltif ${ }^{\mathrm{c}, \mathrm{d}}$, TASSIST Amina ${ }^{\mathrm{b}}$.

\footnotetext{
${ }^{*}$ Laboratoire de Biomatériaux et Phénomènes de Transport, Faculté des Sciences et de la Technologie, UniversitéYahia Fares de Médéa, Pole Universitaire, RN1, Médéa 26000, Algérie.

${ }^{b}$ Laboratoire de Génie de la Réaction, Faculté de Génie Mécanique et Génie des Procédés, UniversitéHouariBoumediene, Bab Ezzouar, Alger, 16111.

${ }^{\mathrm{c}}$ Ecole Nationale Supérieure de Chimie de Rennes, CNRS, UMR 6226, 11 Allée de Beaulieu, CS 50837, 35708 Rennes Cedex 7, France.

${ }^{d}$ Université européenne de Bretagne.
}

Corresponding author Dr. TANDJAOUI Nassima

Laboratoire de Biomatériaux et Phénomènes de Transport, Faculté des Sciences et de la Technologie, Université de Médéa, Pole Universitaire, RN1, Médéa 26000, Algérie.

Ecole Nationale Supérieure de Chimie de Rennes, CNRS, UMR 6226, 11 Allée de Beaulieu, CS 50837, 35708 Rennes Cedex 7, France.

Tel/Fax : +213777561340/+21325581687

E-mail :<nassima_2900@yahoo.fr>; 


\section{Highlights}

A new technique for 2-CP removal coupling absorption to biodegradation was used.

The partition coefficient air- silicone oil of 2-CP was determined.

Silicone oil (47V20) allowed the reduction of 2-CP concentration in gas phase five times lower.

$70 \%$ of 2-CP degradation in silicone oil was achieved using cross-linked enzyme aggregates of BRP peroxidase (BRP-CLEAs). 


\begin{abstract}
This study proposes a new technique to treat waste air containing 2-Chlorophenol (2$\mathrm{CP}$ ), namely an integrated process coupling absorption of the compound in an organic liquid phase and its enzymatic degradation. Silicone oil (47V20) was used as an organic absorbent to allow the volatile organic compound (VOC) transfer from the gas phase to the liquid phase followed by its degradation by means of Cross-linked Brassica rapa peroxidase (BRP) contained in the organic phase. An evaluation of silicone oil (47V20) absorption capacity towards 2-CP was first accomplished by determining its partition coefficient $(\mathrm{H})$ in this solvent. The air-oil partition coefficient of 2-CP was found equal to $0.136 \mathrm{~Pa} \mathrm{~m}^{3} \mathrm{~mol}^{-1}$, which is five times lower than the air-water value $\left(0.619 \mathrm{Pam}^{3} \mathrm{~mol}^{-}\right.$ $\left.{ }^{1}\right)$.The absorbed 2-CP was then subject to enzymatic degradation by cross-linked BRP aggregates (BRP-CLEAs). The degradation step was affected by four parameters (contact time; 2-CP, hydrogen peroxide and enzyme concentrations), which were optimized in order to obtain the highest conversion yield. A maximal conversion yield of $69 \%$ and a rate of $1.58 \mathrm{mg} \mathrm{L}^{-1} \mathrm{~min}^{-1}$ were obtained for 100 minutes duration time when 2-CP and hydrogen peroxide concentrations were respectively $80 \mathrm{mg} \mathrm{L}^{-1}$ and $6 \mathrm{mM}$ in the presence of $2.66 \mathrm{UImL}^{-1}$ BRP-CLEAs. The reusability of BRP-CLEAs in silicone oil was assessed, showing promising results since 59\% of their initial efficiency remained after three batches.
\end{abstract}

Keywords: Absorption; VOC treatment; 2-Chlorophenol; Enzymatic degradation; CLEAs, Brassica rapa peroxidase.

\title{
1. Introduction
}

Among the phenolic compounds, chlorinated phenols (CPs) are a major group of pollutants which are used in various industrial processes as pesticides, herbicides, fungicides, disinfectants, antiseptics, wood and glue preservatives, paints, solvents and as intermediates in the production of dyes and pharmaceuticals (Nicolella et al., 2009; Olaniran and Igbinosa, 2011). They penetrate the atmosphere through volatilization and combustion of coal or wood (Olaniran and Igbinosa, 2011). The evaporation of chlorophenols may occur also from shallow surface waters, when ambient temperature is above $20{ }^{\circ} \mathrm{C}$. Among chlorinated phenols, mono and di- Chlorophenols are the most volatile derivatives. 
2-chlorophenol (2-CP) belongs to the 19 possible congeners of chlorophenols ; it is the most volatile, characterized by a vapour pressure of $0.99 \mathrm{mmHg}$ and could be found frequently in municipal waste incinerators (Olaniran and Igbinosa, 2011; Szatkowski and Dybala-Defratyka, 2013). Physical technologies, such as activated carbon adsorption, are only partial up-stream technologies and could not be considered as efficient methods for CP removal (Li et al., 2011). Advanced oxidation processes (AOP) are among the most used methods for chlorophenols elimination (Pera-Titus et al., 2004; Sung and Huang, 2007). Despite their efficiency, AOPs could be a source of undesirable by-products. Atmospheric pollution by $\mathrm{CP}$ could be also treated by biofiltration (Nicolella et al., 2009). However, and even if microbial degradation of chlorophenols was reported by several authors as an efficient cost effective method (Field and Sierra-Alvarez, 2008), chlorophenols at high concentration could be inhibitory for a wide range of microorganisms (Marsolek et al., 2006). During the last decade, more attention has been paid to the use of enzymes as potential catalysts for the degradation of recalcitrant compounds including phenolic compounds (Kirk et al., 2002).

As catalysts in aqueous phase, enzymes like peroxidases have been used since decades in emerging process of wastewater charged in phenolic compounds (Bansal and Kanwar, 2013; Bayramoğlu and Arıca, 2008; Nazari et al., 2007). Enzymatic treatment using peroxidase and hydrogen peroxide as a co-substrate was proposed in the early 1980s as an alternative treatment, which is highly selective and efficient for removing phenols from aqueous solutions (Klibanov et al., 1980).Enzymatic polymerization offers the advantages of low process energy requirements as well as low solubility of the polymerized product.

The use of organic solvents as reaction media can also greatly expand the repertoire of enzyme-catalysed transformations.In order to overcome the denaturing effect of organic solvents on enzymes, methods such as enzyme cross-linking were developed (Sheldon et al., 2006). A number of potential applications of enzymes, which are either impossible or marginal in water, due for instance to limited solubility of substrate or reaction shift due to the presence of water, become quite feasible and commercially attractive in other solvents (Illanes et al., 2012; Klibanov, 2001). Hence, hydrophobic volatile atmospheric pollutants could be transferred in an organic phase to undergo a rapid, efficient enzymatic treatment under mild conditions. Since chlorophenols presents a limited solubility in water, silicone oil (Rhodorsil ${ }^{\circledR} 47 \mathrm{~V} 20$ ) was used as a 
solvent for their absorption. Indeed, the effectiveness of silicone oil as an alternative absorbent for VOCs was reported in recent studies by several authors (Darracq et al., 2010, 2012; Dumont et al., 2006, 2010).

In the current research, a new combined method was conducted at laboratory-scale for the degradation of 2-CPfrom air streams by absorption into silicone oil followed by enzyme degradation by cross-linked Brassica rapa peroxidase aggregates (BRPCLEAs). Effects of parameters, like substrate, enzyme concentrations and contact time on process efficiency were also evaluated.

\section{Materials and methods}

\subsection{Reagents, silicone oil and peroxidase}

The substrates, 2-CP (99.9\%), hydrogen peroxide (30\%, v:v), guaiacol $(98 \%)$ and the reagents, glutaraldehyde (25\% solution in water), hexane (99.9\%), were all of analytical grade and obtained from Fluka and Sigma-Aldrich (Saint Quentin Fallavier, France).

The polydimethylsiloxane or Silicone oil (Rhodorsil@ 47V20) was purchased from the Rhodia Company (Boulogne-Billancourt, France). It is characterized by a molecular weight ranging between 2800 and $3200 \mathrm{~g} \mathrm{~mol}^{-1}$, a viscosity and density of $20 \mathrm{mPa}$ s and $950 \mathrm{~kg} \mathrm{~m}^{-3}$ respectively at $25^{\circ} \mathrm{C}$ and a dielectric constant of 2.68 (Bluestar silicones, 2012)

Peroxidase was extracted from Brassica rapa turnip bought from local market of Medea city, Algeria.

\subsection{Procedure for BRP-CLEAs preparation}

The cross-linked enzyme aggregates were prepared using the standard method described by Sheldon,(Sheldon, 2011) and has already been optimized in a previous work (Tandjaoui et al., 2015).Crude peroxidase was extracted from fresh turnips of about 13 to $15 \mathrm{~cm}$ using an automatic juice extractor. The juice obtained was filtered by four layers of cheesecloth. The filtrate was stored at $4{ }^{\circ} \mathrm{C}$ after the determination of its residual activity. To prepare BRP-CLEAs, three volumes of ice-cold acetone was added to $12 \mathrm{~mL}$ of crude peroxidase extract diluted with phosphate buffer solution (10 $\mathrm{mM}, \mathrm{pH}=7)$. The mixture was then cross-linked using glutaraldehyde solution $(25 \%$ in water ) at a volume concentration of $2 \%$, and after $3 \mathrm{~h}$ of magnetic agitation at $300 \mathrm{rpm}$, 
the mixture was centrifuged and the BRP-CLEAs formed were washed thoroughly with distilled water and stored in phosphate buffer $(50 \mathrm{mM}, \mathrm{pH}=7)$ at $4^{\circ} \mathrm{C}$.

\subsection{Activity assay for peroxidase}

Activity of cross-linked Brassica rapa peroxidase was measured by the guaiacol colorimetric assay (Egley et al., 1983; Singh et al., 2012). The reaction solution containing $3.9 \mathrm{~mL}$ of $50 \mathrm{mM}$ sodium phosphate buffer $\mathrm{pH}=7.0$ and $4.05 \mu \mathrm{L}$ of guaiacol (98\%) was mixed with $2 \mathrm{mg}$ of CLEAs or $90 \mu \mathrm{L}$ of crude peroxidase. $5 \mu \mathrm{L}$ of hydrogen peroxide $(0.8 \mathrm{M})$ was then added quickly to initiate the reaction. The colour development was monitored at $470 \mathrm{~nm}$ using Shimadzu UV-VIS spectrophotometer (model UV mini-1240 with a molar extinction coefficient value of $4279 \mathrm{M}^{-1} \mathrm{~cm}^{-1}$ ) (Marne-la-Vallée, France). One unit (1.0 U) of peroxidase activity was defined as the amount of enzyme protein that catalyzes the oxidation of $1.0 \mu \mathrm{mol}$ of hydrogen peroxide per min at $25^{\circ} \mathrm{C}$ and $\mathrm{pH}=7$.

\subsection{Analytical method}

The 2-CP concentrations in the gas phase and in silicone oil were determined using gas chromatography (GC- thermo Focus) equipped with aflame ionisation detector (FID), using an $\mathrm{RTx}^{-1}$ column $(15 \mathrm{~m} \times 0.32 \mathrm{~mm})$ with $0.25 \mu \mathrm{m}$ thickness of film. The chromatographic operating conditions are as follows: high-purity nitrogen was used as the carrier gas at a flow rate of $21 \mathrm{ml} \cdot \mathrm{min}^{-1}$. Detector temperature was $202{ }^{\circ} \mathrm{C}$. Injector temperatures were $140{ }^{\circ} \mathrm{C}$ for the gas phase and $220^{\circ} \mathrm{C}$ in the case of silicone oil, while oven temperatures were maintained at $120^{\circ} \mathrm{C}$ and $140{ }^{\circ} \mathrm{C}$ for the gas phase and silicone oil respectively.

\subsection{Partition coefficient determination}

In order to evaluate the capacity of silicone oil to absorb 2-CP, liquid/air partition coefficients of 2-CP in pure water and silicone oil (Rhodorsil® 47V20) were determined at $25^{\circ} \mathrm{C}$ using a static method (Darracq et al., 2010, 2012; Dumont et al., 2010). For this purpose, $5 \mathrm{~mL}$ of silicone oil (47V20) or pure water were introduced in glass vials of $22 \mathrm{~mL}$, closed with PTFE-coated silicone rubber septa (PerkinElmer, France) and sealed with aluminium caps. A precise volume of 2-CP was injected in the 
vials using a $100 \mu \mathrm{L}$ micro-syringe. The vials were placed in a swivel support in a laboratory thermostatic oven at $25{ }^{\circ} \mathrm{C}$ and kept under agitation for $72 \mathrm{~h}$. Once the equilibrium between the two phases was reached, a sample $(500 \mu \mathrm{L})$ was withdrawn from the gas phase of each vial to be analysed using gas chromatography (GC-FID) under the conditions described above. The partition coefficient was defined according to Eq. (1) (Darracq et al., 2010).

$\mathrm{H}_{2 \mathrm{CP}}=$ R.T.H' (Eq.1)

$\mathrm{H}^{\prime}$ is the dimensionless partition coefficient calculated from Eq. (2):

$\mathrm{H}^{\prime}=\left[\frac{C_{g}}{C_{l}}\right] \quad(\mathrm{Eq} .2)$

Where $C_{g}$ and $C_{1}$ are the concentrations of 2-CP in gas and liquid phases respectively after equilibrium $\left(\mathrm{mg} \mathrm{L}^{-1}\right) . \mathrm{R}$ is the universal ideal gas constant $\left(8.314 \mathrm{~Pa} \mathrm{~m}^{3} \mathrm{~mol}^{-1} \mathrm{~K}^{-1}\right)$; $\mathrm{T}$ is the temperature (K). 2-CP concentration in the gas phase $\mathrm{C}_{\mathrm{g}}$ was calculated using a calibration curve built by injection of a known amount of 2-CP using $10 \mu \mathrm{L}$ liquid micro-syringe in $1 \mathrm{~L}$ calibrated glass balloons equipped with magnetic stirrer and sealed with a stopper provided with a Teflon-coated. $\mathrm{C}_{1}$ was deduced from the mass balance after equilibrium was reached.

\subsection{2-Clorophenol degradation by BRP-CLEAs}

Experiments were carried out at a laboratory scale in $22 \mathrm{~mL}$ glass vials; every vial represented a single batch. A volume $(5 \mathrm{~mL})$ of silicone oil containing 2-CP at a specific concentration was introduced in the vials with $5 \mathrm{mg}$ of BRP-CLEAs. Different volumes of 2-CP were introduced into the vials from a concentrated solution $\left(1 \mathrm{~g} \mathrm{~L}^{-1}\right)$ in order to obtain the desired concentration. Vials were hermetically closed with PTFE-coated silicone rubber septa. To start up the reaction, $5 \mu \mathrm{L}$ of hydrogen peroxide were injected through the rubber septa at $\mathrm{t}=0$ and $\mathrm{t}=10$ minutes. Vials were vigorously shaken using a magnetic stirrer at $600 \mathrm{rpm}$ and were kept under constant temperature $25^{\circ} \mathrm{C}$. At the end of reaction, the mixture was centrifuged and the supernatant was separated from BRP-CLEAs. Residual concentration of 2-CP was measured by diluting the supernatant with pure hexane $(1: 1, \mathrm{v}: \mathrm{v}) ; 2 \mu \mathrm{L}$ of mixture was then analysed by gas chromatography (GC-FID) using the conditions described in section 2.4. 
Degradation experiments were triplicated and similarly joined with control experiments, in order to quantify abiotic degradation of 2-CP resulting from adsorption and chemical or photochemical oxidation. The first control had the same composition than the degradation experiments, namely the same amounts of silicone oil, 2-CP and CLEAs, but without $\mathrm{H}_{2} \mathrm{O}_{2}$; while the second one contained silicone oil, 2-CP, $\mathrm{H}_{2} \mathrm{O}_{2}$, but without CLEAs. In both cases, insignificant reduction (less than 4\%) in the concentration of 2-CP was detected.

Two assessment parameters were considered to achieve the best performances of degradation, namely conversion yield (\%) and initial rate of degradation $\mathrm{V}_{\mathrm{o}}$ (Eq.3):

$\mathrm{V}_{0}\left(\mathrm{mg} \mathrm{L}^{-1} \min ^{-1}\right)=\frac{C_{0}-C_{r}}{t_{f}-t_{0}}$

Where $\mathrm{C}_{0}$ and $\mathrm{C}_{\mathrm{r}}$ are the initial and residual concentrations of 2-CP $\left(\mathrm{mg} \mathrm{L}^{-1}\right)$ in the reaction medium respectively; whereas $t_{0}$ and $t_{f}$ are the initial and final time of reaction (min).

\subsection{SEM analysis}

After degradation essays, BRP-CLEAs surface was analysed by scanning electron microscopy. Samples were prepared by drying and coating with gold palladium using a JEOL JFC1100 sputter coater. Images were obtained with $3500 \times$ magnification using JSM-6301F (JEOL) electron microscope.

\subsection{Reusability test}

Reusability of BRP-CLEAs in 2-CP elimination in silicone oil was evaluated for four consecutive batches. The essay was affected under optimal conditions fixed. After each batch, the mixture was centrifuged, the supernatant was decanted, and BRP-CLEAs were washed with ultrapure water. Particles were then dried to be reused in the next cycle. The reusability was assessed by measuring the relative efficiency against the first batch, namely according to the following relation (Eq. 4) :

$$
\text { Relative efficiency }=\frac{\text { Conversion of batch } x}{\text { Conversion of first batch }} \times 100
$$

\section{Results and discussion}

\subsection{BRP-CLEAs}


The BRP-CLEAs prepared showed a high stability toward physicochemical agents such as temperature and $\mathrm{pH}$. They were also characterized by a considerable activity in hydrophobic solvents such as hexane and silicone oils (47V5 and 47V20) compared to hydrophilic ones (Tandjaoui et al., 2015). Accounting for the choice of silicone oil as a solvent for this enzymatic reaction, and hence to absorb the VOC, 2-CP, present in the gas phase.

\subsection{Partition coefficient}

Partition coefficient of 2-CP in water and silicone oil was determined at $25{ }^{\circ} \mathrm{C}$ by injecting increasing amounts of 2-CP in vials. The dimensionless partition coefficient $\mathrm{H}^{\prime}$ was calculated from the slope of the curves representing the equilibrium concentration of 2-CP in the gas phase $\left(\mathrm{C}_{\mathrm{g}}\right)$ versus its concentration in the liquid phase $\left(\mathrm{C}_{1}\right)$. The obtained values of $\mathrm{H}^{\prime}$ were $2 \cdot 5 \cdot 10^{-4}$ and $5 \cdot 5 \cdot 10^{-5}$ in pure water and silicone oil respectively. Whereas, the $\mathrm{H}$ values were 0.619 and $0.136 \mathrm{~Pa} \mathrm{~m}^{3} \mathrm{~mol}^{-1}$ in pure water and silicone oil respectively.

Comparison of the partition coefficients $(\mathrm{H})$ of 2-CP in both phases shows that the $\mathrm{H}$ value in silicone oil (47V20) is five times lower than its value in pure water, demonstrating the higher capacity of silicone oil to absorb this VOC and enhancing thereby the transfer of 2-CP from the gas phase to the organic phase. This result can be explained by the weak polarity of silicone oil, which is characterized by a dielectric constant of 2.68 compared to that of water 78.5, which enhances the interactions with non-polar molecules of 2-CP and therefore decreases the mass transfer constraints in the oil phase.

\subsection{Degradation kinetics}

The 2-CP degradation kinetics was followed during $140 \mathrm{~min}$ and an initial 2-CP concentration ranging from 20 to $200 \mathrm{mg} \mathrm{L}^{-1}$. Hydrogen peroxide concentration and BRP-CLEAs activity were $4 \mathrm{mM}$ and $0.76 \mathrm{UI} \mathrm{mL}^{-1}$ respectively. Samples were withdrawn every 20 minutes. The corresponding degradation profiles are shown in Fig.1a

It can be noticed that in all cases, a significant decrease in 2-CP concentration occurred only during the first 100 minutes, after which the degradation yield remained constant. Reaction time has been considered thereafter; and hence the conversion yield and the initial rate $\left(\mathrm{V}_{0}\right)$ versus the initial 2-CP concentration are shown in Fig. 1b. The initial 
rate increased with the 2-CP concentration until a maximum of $0.183 \mathrm{mg} \mathrm{L}^{-1} \mathrm{~min}^{-1}$ obtained at $120 \mathrm{mg} \mathrm{L}^{-1}$. Beyond this concentration, the degradation rate decreased with increasing 2-CP concentration. Regarding the conversion yield, it decreased for increasing initial 2-CP concentrations, from $28.4 \%$ for $20 \mathrm{mg} \mathrm{L}^{-1}$ to $6 \%$ at $200 \mathrm{mg} \mathrm{L}^{-}$ ${ }^{1}$.Therefore, inhibition by excess of substrate (2-CP) occurred when its concentration was above $120 \mathrm{mg} \mathrm{L}^{-1}$. On the other hand, the decrease in the 2-CP conversion may be due to the accumulation of by-products, which could cause some diffusional limitations of the substrate through the BRP-CLEAs matrix. This hypothesis was supported at the examination of the pictures given by scanning electron microscopy (SEM) of the BRPCLEAs before and after treatment (Fig. 2). The pictures revealed that before use, BRPCLEAs appear with smooth clean surface with amorphous structure while the most important difference observed after their use in 2-CP degradation in silicone oil was the presence of small particles on their surface compared to the size of the BRP-CLEAs ; their morphology also differed to that of BRP-CLEAs. Based on this observation, it could be suggested that the products of the catalytic transformation of 2-CP by BRPCLEAs are the accumulation of insoluble polymers on the surface of CLEAs causing their partial inhibition. For this reason, an adequate washing of CLEAs should be necessary before introducing them in a new catalytic cycle.

\subsection{Effect of the hydrogen peroxide concentration}

Hydrogen peroxide is known as a co-substrate for all peroxidases. $\mathrm{H}_{2} \mathrm{O}_{2}$ concentration was varied from 0.5 to $10 \mathrm{mM}$ by a stepwise addition of volumes $(5 \mu \mathrm{L}$ every 25 minutes) from different concentrated freshly prepared solutions; while other parameters were fixed as follows: $80 \mathrm{mg} \mathrm{L}^{-1}$ of 2-CP and $0.76 \mathrm{UI} \mathrm{mL}^{-1}$ of BRP-CLEAs.

The effect of $\mathrm{H}_{2} \mathrm{O}_{2}$ addition is illustrated in Fig. 3. Similarly to the effect of 2-CP concentration, two ranges of evolution were detected on both curves. First, in the range from 0.5 to $6 \mathrm{mM}$, a significant amount of 2-CP was degraded by BRP-CLEAs and maximal conversion $(31 \%)$ was obtained at an initial rate of $0.247 \mathrm{mg} \mathrm{L}^{-1} \mathrm{~min}^{-1}$. A dramatic decrease of the rate and the yield of conversion were then observed beyond 6 $\mathrm{mM}$ of $\mathrm{H}_{2} \mathrm{O}_{2}$. This phenomenon was also encountered during phenol degradation by peroxidases, as a consequence of the partial inactivation of peroxidases due to the excess of hydrogen peroxide (Bódalo et al., 2008; Deva et al., 2014).

\subsection{Effect of the BRP-CLEAs activity}


Generally, increasing the enzyme amount in the reaction medium has a significant direct effect on the rate of reaction. The influence of this parameter on 2-CP removal was investigated by varyingBRP-CLEAs activity from 0.5 to $3 \mathrm{UI} \mathrm{mL}^{-1}$. Experiments were conducted under optimal conditions $\left(2-\mathrm{CP}=80 \mathrm{mg} \mathrm{L}{ }^{-1} ; \mathrm{H}_{2} \mathrm{O}_{2}=6 \mathrm{mM}\right.$; contact time $=100 \mathrm{~min}$ ). Fig. 4 demonstrates the effect of BRP-CLEAs activity on 2-CP degradation process. When the activity was lower than $1.5 \mathrm{UI} \mathrm{mL}^{-1}$, the conversion yield and the initial rate were less than $50 \%$ and $0.4 \mathrm{mg} \mathrm{L}^{-1} \mathrm{~min}^{-1}$, respectively. Contrarily, maximal conversion (55 to 60\%) was obtained with CLEAs activity equal to or greater than $1.5 \mathrm{UI} \mathrm{mL}^{-1}$.

This result was expected, since the availability of enzyme sites induces the attraction of substrate molecules and subsequently the increase in the number of molecules converted per time-unit.

\subsection{Optimal kinetics}

Under the optimal conditions described above, a kinetic study was conducted in order to monitor the 2-CP concentration with time. From the results displayed in Fig. 5, it appears that in the optimal conditions, more than $60 \%$ of 2-CP were degraded during the first hour; while extending the reaction time until 135 min allowed an enhancement of the conversion to $70 \%$.

\subsection{Reusability of BRP-CLEAs}

An important propriety in immobilised enzyme is its ability to be regenerated along successive cycles. To evaluate the reusability of BRP-CLEAs in silicon oil, the removal efficiency of 2-CP was quantified during four successive cycles. As shown on Fig. 6, BRP-CLEA held on until $60 \%$ of their initial efficiency during the first three batches. However the last experiment revealed a higher decrease of the efficiency. The inhibition of their activity seems to be due to the accumulation of polymer on their surface observed after SEM analyses. This activity loss could be hampered by a washing of the BRP-CLEAs with an appropriate solvent before reuse or by the addition of another compound able to attract the polymer formed. A last solution would consist in withdraw and inject fractions of fresh CLEAs during the operation. Nevertheless, the above 
results should be confirmed on a more important cycle of experiments for a full validation of the process.

\section{Conclusion}

The efficiency of a new combined physical-enzymatic process for the treatment of volatile organic compounds was studied. 2-CP was taken as a model molecule. The first step of the process was the injection of 2-CP into silicone oil which showed strong capacity for absorbing 2-CP when compared to water. The second step consisted in its degradation by cross-linked peroxidase of Brassica rapa contained in the organic medium. The enzymatic conversion showed to be affected by substrate concentration and enzyme loading. The enzymatic reaction might also be limited by the accumulation of by-products on the CLEAs' surface. Nevertheless, the yield of degradation achieved was approximatively $70 \%$ for the conditions fixed after optimization. The reusability of BRP-CLEAs in silicone oil was assessed, showing promising results since $59 \%$ of their initial efficiency remained after three batches. The combined process could be therefore envisaged as a good alternative to chemical or biological treatments as it presents simplicity in design and operation. 


\section{References:}

Bansal, N., and Kanwar, S.S. (2013). Peroxidase(s) in Environment Protection. Sci. World J. 2013, 1-9.

Bayramoğlu, G., and Arıca, M.Y. (2008). Enzymatic removal of phenol and pchlorophenol in enzyme reactor: Horseradish peroxidase immobilized on magnetic beads. J. Hazard. Mater. 156, 148-155.

Bluestar silicones (2012). Rhodorsil® Huiles 47 Information technique.

Bódalo, A., Bastida, J., Máximo, M.F., Montiel, M.C., Gómez, M., and Murcia, M.D. (2008). A comparative study of free and immobilized soybean and horseradish peroxidases for 4-chlorophenol removal: protective effects of immobilization. Bioprocess Biosyst. Eng. 31, 587-593.

Darracq, G., Couvert, A., Couriol, C., Amrane, A., Thomas, D., Dumont, E., Andres, Y., and Le Cloirec, P. (2010). Silicone oil: An effective absorbent for the removal of hydrophobic volatile organic compounds. J. Chem. Technol. Biotechnol. 85, 309-313.

Darracq, G., Couvert, A., Couriol, C., Amrane, A., and Cloirec, P.L. (2012). Removal of Hydrophobic Volatile Organic Compounds in an Integrated Process Coupling Absorption and Biodegradation-Selection of an Organic Liquid Phase. Water. Air. Soil Pollut. 223, 4969-4997.

Deva, A.N., Arun, C., Arthanareeswaran, G., and Sivashanmugam, P. (2014). Extraction of peroxidase from waste Brassica oleracea used for the treatment of aqueous phenol in synthetic waste water. J. Environ. Chem. Eng. 2, 1148-1154.

Dumont, E., Andrès, Y., and Le Cloirec, P. (2006). Mass transfer coefficients of styrene and oxygen into silicone oil emulsions in a bubble reactor. Chem. Eng. Sci. 61, 56125619.

Dumont, E., Darracq, G., Couvert, A., Couriol, C., Amrane, A., Thomas, D., Andrès, Y., and Le Cloirec, P. (2010). Determination of partition coefficients of three volatile organic compounds (dimethylsulphide, dimethyldisulphide and toluene) in water/silicone oil mixtures. Chem. Eng. J. 162, 927-934.

Egley, G.H., Jr, R.N.P., Vaughn, K.C., and Duke, S.O. (1983). Role of peroxidase in the development of water-impermeable seed coats in Sida spinosa L. Planta 157, 224 232.

Field, J.A., and Sierra-Alvarez, R. (2008). Microbial degradation of chlorinated phenols. Rev. Environ. Sci. Biotechnol. 7, 211-241.

Illanes, A., Cauerhff, A., Wilson, L., and Castro, G.R. (2012). Recent trends in biocatalysis engineering. Bioresour. Technol. 115, 48-57.

Kirk, O., Borchert, T.V., and Fuglsang, C.C. (2002). Industrial enzyme applications. Curr. Opin. Biotechnol. 13, 345-351. 
Klibanov, A.M. (2001). Improving enzymes by using them in organic solvents. Macmillan Mag. 409, 241-246.

Klibanov, A.M., Alberti, B.N., Morris, E.D., and Felshin, L.M. (1980). Enzymatic Removal of Toxic Phenols and Anilines from Waste Waters. J Appl Biochem U. S. 2:5.

Li, J., Hu, Y., Lü, W., Shi, L., Sun, Q., Zhou, Y., Xu, J., Wang, J., and Shen, B. (2011). Efficient oxidative degradation of 2-chlorophenol and 4-chlorophenol over supported CuO-based catalysts. J. Nat. Gas Chem. 20, 493-497.

Marsolek, M.D., Kirisits, M.J., and Rittmann, B.E. (2006). Biodegradation of 2,4,5trichlorophenol by aerobic microbial communities: biorecalcitrance, inhibition, and adaptation. Biodegradation 18, 351-358.

Nazari, K., Esmaeili, N., Mahmoudi, A., Rahimi, H., and Moosavi-Movahedi, A.A. (2007). Peroxidative phenol removal from aqueous solutions using activated peroxidase biocatalyst. Enzyme Microb. Technol. 41, 226-233.

Nicolella, C., Converti, A., and Zilli, M. (2009). Biotrickling air filtration of 2chlorophenol at high loading rates. Biochem. Eng. J. 43, 98-105.

Olaniran, A.O., and Igbinosa, E.O. (2011). Chlorophenols and other related derivatives of environmental concern: Properties, distribution and microbial degradation processes. Chemosphere 83, 1297-1306.

Pera-Titus, M., García-Molina, V., Baños, M.A., Giménez, J., and Esplugas, S. (2004). Degradation of chlorophenols by means of advanced oxidation processes: a general review. Appl. Catal. B Environ. 47, 219-256.

Sheldon, R.A. (2011). Characteristic features and biotechnological applications of cross-linked enzyme aggregates (CLEAs). Appl. Microbiol. Biotechnol. 92, 467-477.

Sheldon, R.A., Schoevaart, R., and van Langen, L.M. (2006). Cross-linked enzyme aggregates. In Immobilization of Enzymes and Cells, (Springer), pp. 31-45.

Singh, P., Prakash, R., and Shah, K. (2012). Effect of organic solvents on peroxidases from rice and horseradish: Prospects for enzyme based applications. Talanta 97, 204210.

Sung, M., and Huang, C.P. (2007). Kinetics of the degradation of 2-chlorophenol by ozonation at pH 3. J. Hazard. Mater. 141, 140-147.

Szatkowski, L., and Dybala-Defratyka, A. (2013). A computational study on enzymatically driven oxidative coupling of chlorophenols: An indirect dehalogenation reaction. Chemosphere 91, 258-264.

Tandjaoui, N., Tassist, A., Abouseoud, M., Couvert, A., and Amrane, A. (2015). Preparation and characterization of cross-linked enzyme aggregates (CLEAs) of Brassica rapa peroxidase. Biocatal. Agric. Biotechnol. 4, 208-213. 


\section{Figure captions:}

Fig .1. Kinetics of 2-CP degradation in silicone oil for 2-CP concentrations ranging from 20 to $200 \mathrm{mg} \mathrm{L}^{-1}$. (a) time-courses of 2-CP degradation, (b) Effect of initial 2-CP concentration, (Reaction conditions: $5 \mathrm{~mL}$ of silicone oil, $4 \mathrm{mM} \mathrm{H}_{2} \mathrm{O}_{2}, 0.76 \mathrm{UI} \mathrm{mL}^{-1}$ of BRP-CLEAs at $\left.25^{\circ} \mathrm{C}\right)$.

Fig .2. SEM of BRP-CLEAs, before and after use for 2-CP degradation in silicone oil (47V20).

Fig .3. Effect of the initial $\mathrm{H}_{2} \mathrm{O}_{2}$ concentration on initial rate and conversion yield (5mL of silicone oil, $80 \mathrm{mg} \mathrm{L}^{-1}$ of 2-CP, $0.76 \mathrm{UImL}^{-1}$ of BRP-CLEAs at $25^{\circ} \mathrm{C}$ ).

Fig .4. Effect of the BRP-CLEAs activity on the initial rate and the conversion yield (Reaction conditions: $5 \mathrm{~mL}$ of silicone oil, $80 \mathrm{mg} \mathrm{L}^{-1}$ of $2-\mathrm{CP}, 6 \mathrm{mM} \mathrm{H}_{2} \mathrm{O}_{2}$ at $25^{\circ} \mathrm{C}$ ).

Fig .5. Effect of the contact time on the 2-CP concentration and the conversion yield under optimal conditions (Reaction conditions: $5 \mathrm{~mL}$ of silicone oil, $80 \mathrm{mg} \mathrm{L}^{-1}$ of 2-CP, $6 \mathrm{mM} \mathrm{H}_{2} \mathrm{O}_{2}, 2.66 \mathrm{UImL}^{-1}$ of BRP-CLEAs at $25^{\circ} \mathrm{C}$ ).

Fig .6. Reusability of BRP-CLEAs for 2-CP removal in batch processes (Reaction conditions: $5 \mathrm{~mL}$ of silicone oil, $80 \mathrm{mg} \mathrm{L}^{-1}$ of 2-CP, $6 \mathrm{mM} \mathrm{H}_{2} \mathrm{O}_{2}, 2.66 \mathrm{UI}$ $\mathrm{mL}^{-1}$ of BRP-CLEAs at $25^{\circ} \mathrm{C}$ ). 
(a)

(b)
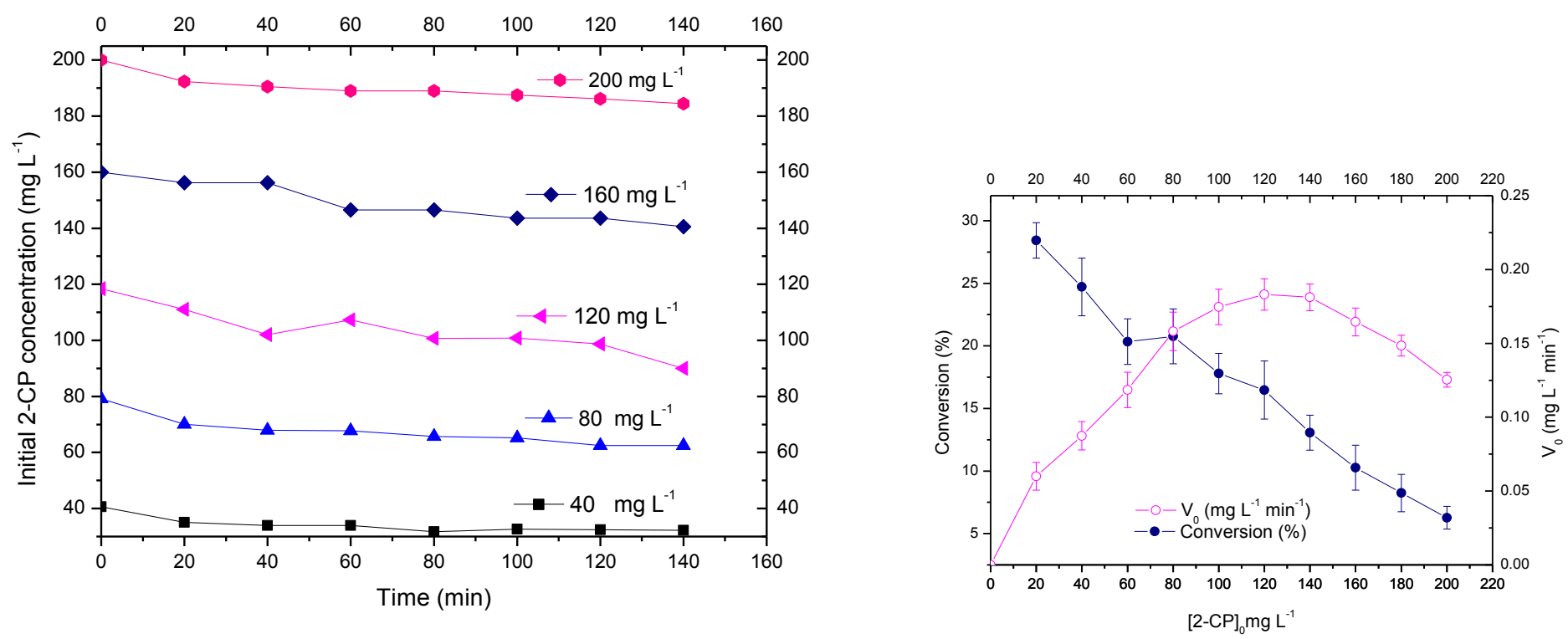

Fig .1. Kinetics of 2-CP degradation in silicone oil for 2-CP concentrations ranging from 20 to $200 \mathrm{mg} \mathrm{L}^{-1}$ (a) time-courses of 2-CP degradation, (b) Effect of initial 2-CP concentration, (Reaction conditions: $5 \mathrm{~mL}$ of silicone oil, $4 \mathrm{mM} \mathrm{H}_{2} \mathrm{O}_{2}, \quad 0.76 \mathrm{UI}$ $\mathrm{mL}^{-1}$ of BRP-CLEAs at $25^{\circ} \mathrm{C}$ ).

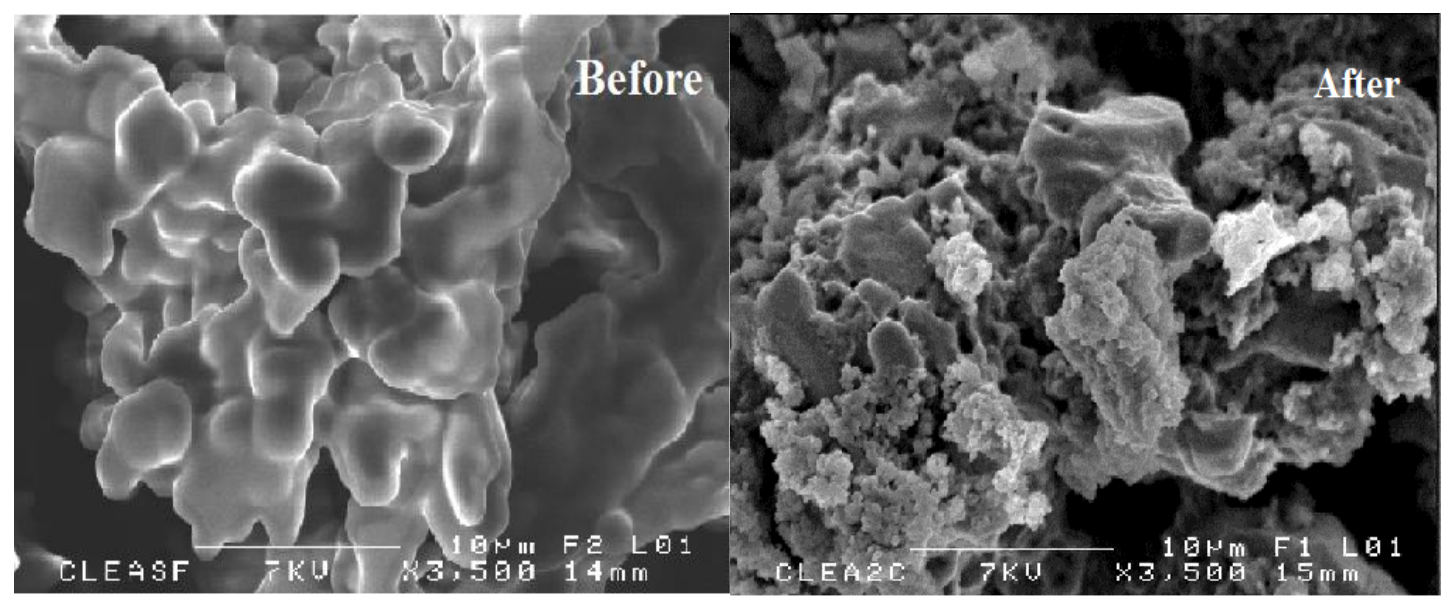

Fig .2. SEM of BRP-CLEAs, before and after use for 2-CP degradation in silicone oil (47V20). 


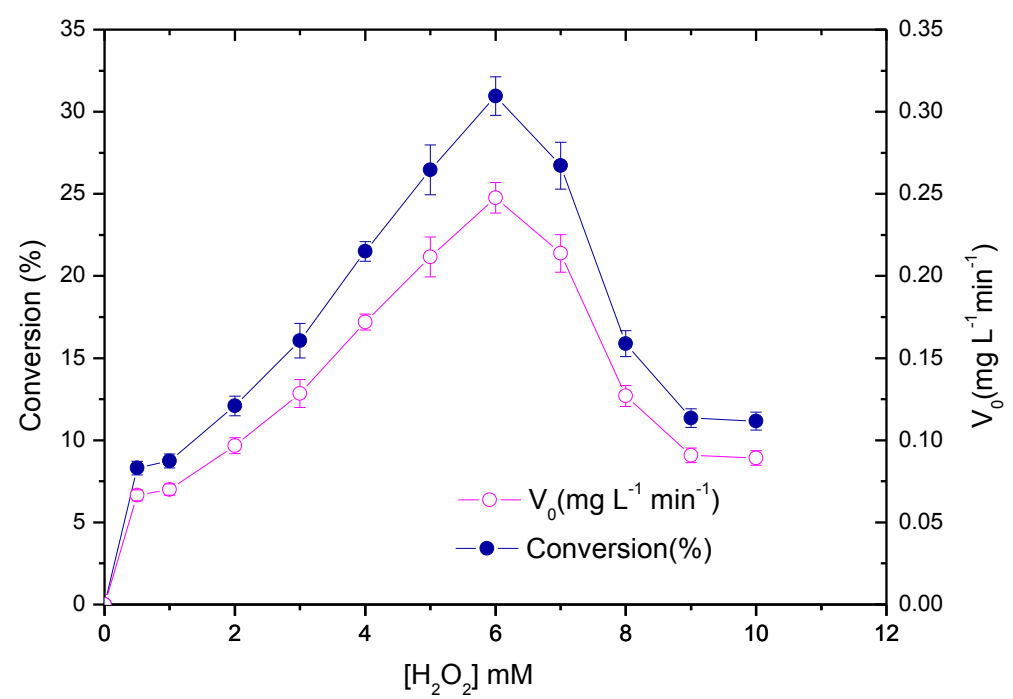

Fig .3. Effect of the initial $\mathrm{H}_{2} \mathrm{O}_{2}$ concentration on initial rate and conversion yield ( $5 \mathrm{~mL}$ of silicone oil, $80 \mathrm{mg} \mathrm{L}^{-1}$ of $2-\mathrm{CP}, 0.76 \mathrm{UI} \mathrm{mL}^{-1}$ of BRP-CLEAs at $25^{\circ} \mathrm{C}$ ).

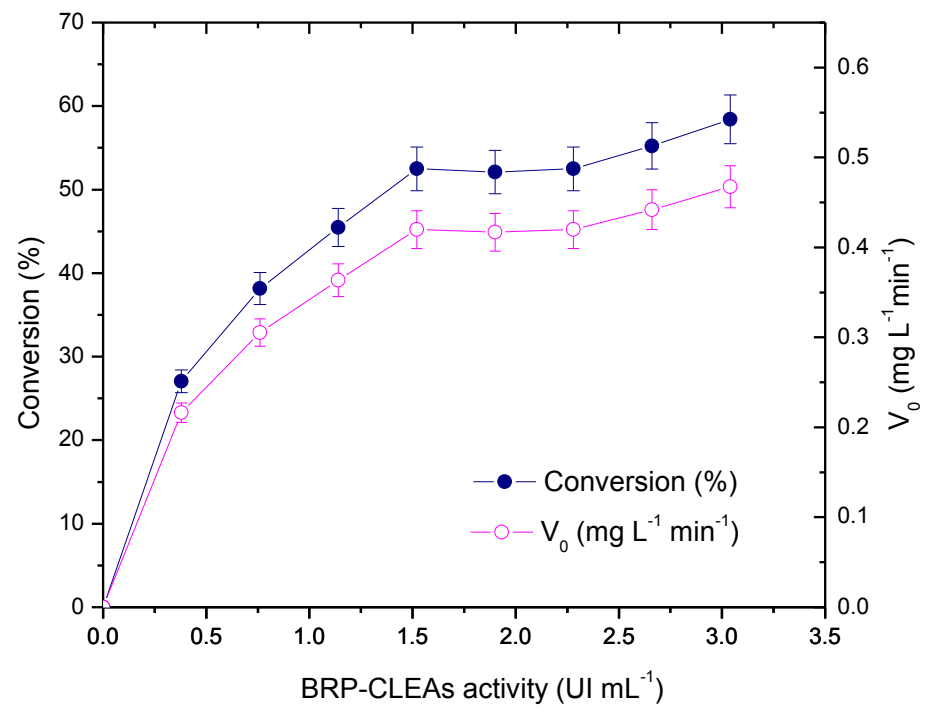

Fig. 4. Effect of the BRP-CLEAs activity on the initial rate and the conversion yield (Reaction conditions: $5 \mathrm{~mL}$ of silicone oil, $80 \mathrm{mg} \mathrm{L}^{-1}$ of 2-CP, $6 \mathrm{mM} \mathrm{H}_{2} \mathrm{O}_{2}$ at $25^{\circ} \mathrm{C}$ ). 


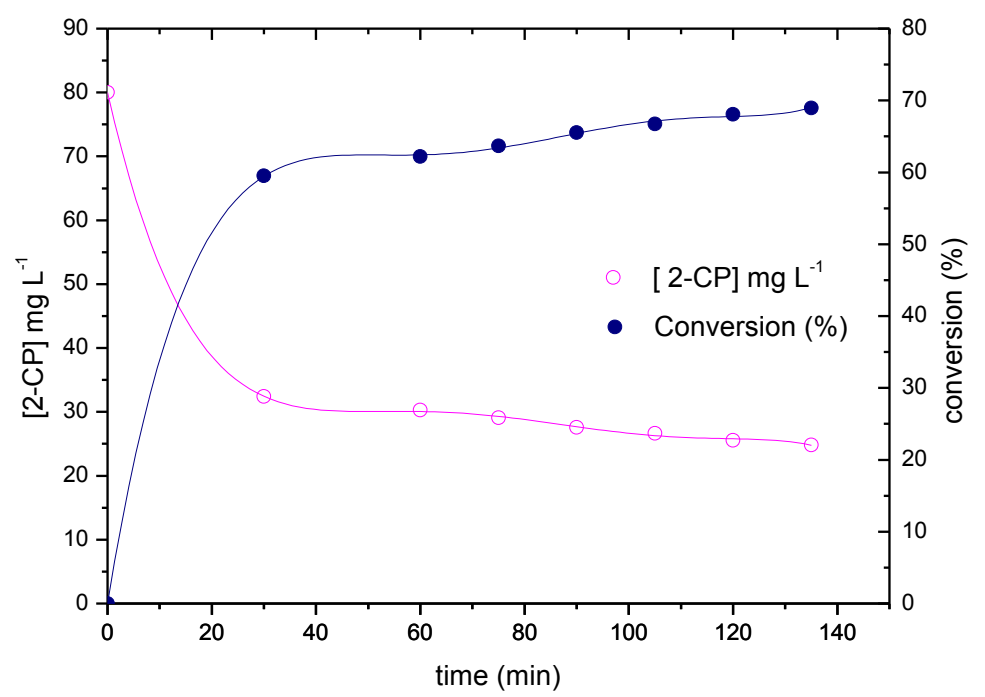

Fig .5. Effect of the contact time on the 2-CP concentration and the conversion yield under optimal conditions (Reaction conditions: $5 \mathrm{~mL}$ of silicone oil, $80 \mathrm{mg} \mathrm{L}^{-1}$ of 2-CP, $6 \mathrm{mM} \mathrm{H}_{2} \mathrm{O}_{2}, 2.66 \mathrm{UI} \mathrm{mL}^{-1}$ of BRP-CLEAs at $25^{\circ} \mathrm{C}$ ).

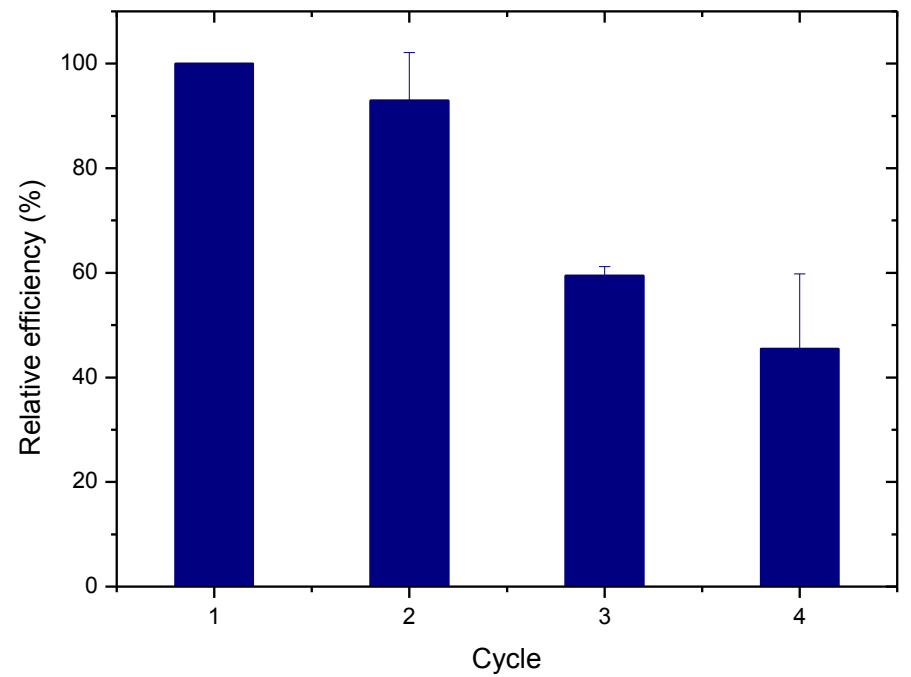

Fig .6. Reusability of BRP-CLEAs for 2-CP removal in batch processes (Reaction conditions: $5 \mathrm{~mL}$ of silicone oil, $80 \mathrm{mg} \mathrm{L}^{-1}$ of 2-CP, $6 \mathrm{mM} \mathrm{H}_{2} \mathrm{O}_{2}, 2.66 \mathrm{UI}$ $\mathrm{mL}^{-1}$ of BRP-CLEAs at $25^{\circ} \mathrm{C}$ ). 